\title{
Mineralogical Characterization of Aeolian Sands from Inner Mongolia, China
}

\author{
Brian Nzuki1,2, Liqun Luo ${ }^{1}$, Pengfei Zhou ${ }^{1}$, Christophe Niyonzima' ${ }^{1}$ Xu Tu${ }^{1}$ \\ ${ }^{1}$ School of Resources and Environmental Engineering, Wuhan University of Technology, Wuhan, China \\ ${ }^{2}$ Department of Mining, Materials and Petroleum Engineering, Jomo Kenyatta University of Agriculture and Technology, Nairobi, \\ Kenya \\ Email: *luoliqun@whut.edu.cn
}

How to cite this paper: Nzuki, B., Luo, L.Q., Zhou, P.F., Niyonzima, C. and Tu, X. (2019) Mineralogical Characterization of Aeolian Sands from Inner Mongolia, China. Journal of Minerals and Materials Characterization and Engineering, 7, 81-102. https://doi.org/10.4236/jmmce.2019.73007

Received: March 18, 2019

Accepted: April 9, 2019

Published: April 12, 2019

Copyright $\odot 2019$ by author(s) and Scientific Research Publishing Inc. This work is licensed under the Creative Commons Attribution International License (CC BY 4.0).

http://creativecommons.org/licenses/by/4.0/

\begin{abstract}
Aeolian sand sample from Tengger desert, located in the southern part of Inner Mongolia (China) was characterized for major elemental composition and mineralogy by EPMA, XRF and XRD methods. The objective of this research was to provide data which would be a guide to aid future beneficiation of this sand, especially for the economic exploitation of feldspar and quartz which have a wide range of applications in various industries like plastic, paint, ceramics and glass industries. The elemental analysis of the sample was carried out by X-ray fluorescence spectrometer and chemical analysis while the minerals present were identified by an $\mathrm{X}$-ray diffraction analyzer. The sand was discovered to contain basically $\mathrm{SiO}_{2}$ (82.43\%), $\mathrm{Al}_{2} \mathrm{O}_{3}$ (7.68\%), $\mathrm{Na}_{2} \mathrm{O}$ $+\mathrm{K}_{2} \mathrm{O}(4.37 \%)$ and $\mathrm{TiO}_{2}$ and $\mathrm{Fe}_{2} \mathrm{O}_{3}$ as the main impurities. It was also discovered that grinding of the sand is required to enhance the liberation of the minerals and the separation methods recommended are magnetic separation and flotation. It was therefore concluded that aeolian sand is a suitable source of quartz and feldspar for use in the industry.
\end{abstract}

\section{Keywords}

Aeolian Sands, Mineralogy, Feldspar, Quartz, Microzones

\section{Introduction}

Aeolian sands are finely to relatively medium grained, uniformly graded materials deposited in huge amounts by wind, mostly in deserts [1]. Feldspar and quartz are the main mineral constituents of aeolian sands [2]. Most of the deserts in China host vast amounts of sands which contain valuable minerals which can be exploited economically, and the tailings used for planting trees 
and grass since they contain essential minerals for flora growth. The main purpose of the mineralogical characterization in this study was to determine whether there are sufficient feldspar and quartz minerals that can be exploited economically for various industrial uses. Since feldspar and quartz have a wide range of uses as raw materials in ceramics, plastic, paint, rubber, electronic and glass industries, detailed elemental content determination of this deposit was necessary [3] [4].

In addition, the associated minerals were also identified as it is of great importance in case the deposit needs to be processed. This is because different industries give certain specifications on the maximum impurity percentage contamination to be acceptable in the raw materials. For instance, iron contamination must be below $0.15 \%$ in feldspar as a raw material in the manufacture of ceramics [5]. Previous studies have reported titanium and iron minerals being associated with quartz and feldspar resources [4] [6].

In order to satisfactorily characterize the samples, different approaches were used. The EPMA technique which is a non-destructive method was one of the methods used. It is a widely used technique where the solid specimens are bombarded with a focused electron beam and the emitted X-rays analyzed to determine the composition, concentration and distribution of the elements in the specimen [7]. Wavelength-dispersive spectroscopy (WDS) and energy-dispersive spectroscopy (EDS) analytical systems are the two techniques applied in this method. The EDS technique is quick and is used to identify the major elements while the WDS technique, though slow, is more detailed and identifies the trace elements such as the impurities [8]. Optical microscopes were also used to investigate the surfaces of different polished thin sections of the samples since comprehensive mineralogical investigation of samples by microscopy is a critical part of any study of an ore deposit [9]. In this paper, aeolian sand samples from Tengger desert, Inner Mongolia Province (China), are investigated for major elemental composition and mineralogy undertaken by EPMA, XRF and XRD methods. The desert is located in the southern part of Inner Mongolia and is well-known for aeolian sand deposits. This study, therefore, provides detailed ore characteristics, composition and mineralogy data which can be used for the future beneficiation of this kind of aeolian sands since little is known about their properties.

\section{Experimental}

\subsection{Materials}

Experimental study samples were collected from the Inner Mongolia Tengger Desert open-pit mine using the sample points method. 2200 kilograms of ore from 15 sub-sample points were packed in 45 bags and used in the Mineral Processing Engineering laboratory in Wuhan University of Technology for the various tests and studies. The sample information of each sample point is shown in Table 1. Samples were referred to as TG samples for subsequent study tests. 
Table 1. Sample points information of the aeolian sands.

\begin{tabular}{cccc}
\hline Point serial number & Distance $(\mathrm{km})$ & Number of bags (bags) & Gap $(\mathrm{km})$ \\
\hline 1 & 30 & 3 & 0 \\
2 & 31 & 3 & 1 \\
3 & 32 & 3 & 2 \\
4 & 34 & 3 & 4 \\
5 & 35 & 3 & 5 \\
6 & 37 & 3 & 7 \\
7 & 38 & 3 & 8 \\
8 & 39 & 3 & 9 \\
9 & 40 & 3 & 10 \\
10 & 41 & 3 & 11 \\
11 & 42 & 3 & 12 \\
12 & 44 & 3 & 14 \\
13 & 45 & 3 & 15 \\
14 & 51 & 3 & 21 \\
15 & 53 & 3 & 23 \\
\hline
\end{tabular}

\subsection{Methods}

In order to understand the sample characteristics of each sample point, the samples were thoroughly mixed separately, and test samples prepared for further analysis. Subsequent test samples were prepared by mixing representative samples from the 15 points for laboratory mineral identification and the various laboratory tests.

Particle size analysis is usually significant in evaluating the performance of a grinding circuit [10]. In this study, it was used to determine the size range and distribution of the sand. A sieve test analysis of 6 points from the 15 points which included points $1,4,7,10,13$ and 15 was undertaken.

The elemental analysis of the sample was carried out by X-ray fluorescence spectrometer and chemical analysis while the minerals present were identified by an X-ray diffraction analyzer to determine whether the main minerals in the deposit, such as feldspar, had sufficient content to be used for different uses such as the ceramic industries [11]. Atomic absorption spectroscopy method was used in the chemical analysis of the TG mixed sample. The main multi-element chemical analysis results are shown in Table 6.

A representative sample of the ore of minus $2 \mathrm{~mm}$ in size was mixed with epoxy resin to prepare a polished thin section. An optical microscope (Olympus BX51 model) was then used to observe and determine the minerals present as well as their dissemination sizes.

A comprehensive main and trace elements ore data, as well as detailed optical mineralogy, petrographic examination and mineral composition data was carried out using an electron microprobe analyzer (EMPA) [12]. In order to ascer- 
tain the microscopic and chemical composition characteristics of quartz, feldspar and the gangue minerals present, electron microprobe and energy spectrum microzone analyses were performed.

\section{Results and Discussions}

\subsection{Particle Size Analysis}

Sieve test and laser sizing particle analysis techniques (Table 2, Table 3 and Figure 1) showed that TG-1 and TG-10 samples are relatively fine, while TG-4 and TG-13 samples are coarser. The coarseness of the remaining samples (TG-7 and TG-15) was intermediate, with the size of most particles of the sample being mainly concentrated in the range of -0.30 to $+0.125 \mathrm{~mm}$ (Table 2) which accounted for about $80 \%$ of the total particles in all samples. The average particle size of statistical results of granularity analysis on Tengger aeolian sand D10, D50 and D90 is $133.5 \mu \mathrm{m}, 240.3 \mu \mathrm{m}$ and $451.8 \mu \mathrm{m}$ respectively as shown is Table 3 and Figure 1. From the particle size results of these samples, it means that grinding should be the first stage in the beneficiation of these aeolian sands.

\subsection{Mineralogy and Chemical Composition of the Aeolian Sands}

The sample appears to be yellow-brown/light yellow to grayish-white in colour

Table 2. TS samples sieve test results of six selected points.

\begin{tabular}{cccccccc}
\hline $\begin{array}{c}\text { Aperture size } \\
(\mathrm{mm})\end{array}$ & $\begin{array}{c}\text { Mesh } \\
\text { number }\end{array}$ & TG-1 $(\%)$ & $\begin{array}{c}\text { TG-4 } \\
(\%)\end{array}$ & TG-7 (\%) & TG-10 (\%) & $\begin{array}{c}\text { TG-13 } \\
(\%)\end{array}$ & TG-15 (\%) \\
\hline 0.45 & +40 & $\begin{array}{c}\text { Small } \\
\text { amount }\end{array}$ & 0.55 & $\begin{array}{c}\text { Small } \\
\text { amount }\end{array}$ & $\begin{array}{c}\text { Small } \\
\text { amount }\end{array}$ & 0.55 & $\begin{array}{c}\text { Small } \\
\text { amount }\end{array}$ \\
$-0.45+0.30$ & $-40+60$ & 1.40 & 21.44 & 8.44 & 1.74 & 18.45 & 11.25 \\
$-0.30+0.20$ & $-60+80$ & 16.29 & 23.19 & 36.28 & 15.13 & 19.20 & 24.31 \\
$-0.20+0.15$ & $-80+100$ & 31.19 & 17.04 & 23.02 & 28.12 & 16.84 & 23.80 \\
$-0.15+0.125$ & $-100+120$ & 39.41 & 26.04 & 23.37 & 42.81 & 27.32 & 28.34 \\
$-0.125+0.074$ & $-120+200$ & 11.31 & 10.69 & 8.29 & 11.70 & 16.44 & 11.60 \\
-0.074 & -200 & 0.40 & 1.05 & 0.60 & 0.50 & 1.20 & 0.71 \\
\hline
\end{tabular}

Note: "small amount" in Table 2 means less than $0.5 \%$.

Table 3. Laser sizing statistical results of granularity analysis on Tengger aeolian sands.

\begin{tabular}{cccc}
\hline Sample & D10 $(\mu \mathrm{m})$ & D50 $(\mu \mathrm{m})$ & D90 $(\mu \mathrm{m})$ \\
\hline TG1 & 133.9 & 216.0 & 355.3 \\
TG4 & 138.6 & 261.7 & 517.7 \\
TG7 & 138.5 & 253.5 & 479.9 \\
TG10 & 119.2 & 198.7 & 337.8 \\
TG13 & 132.1 & 253.4 & 512.3 \\
TG15 & 138.5 & 258.7 & 508.0 \\
Average & 133.5 & 240.3 & 451.8 \\
\hline
\end{tabular}


under naked eyes and has a grainy texture. From microscopic observations, the main metal minerals include pyrite, magnetite and ilmenite. Mainly, the transparent minerals are quartz, potassium feldspar, plagioclase, sand cuttings, sericite and epidote. The sample chemical analysis results of typical elements in TG samples are shown in Table 4.

From the analysis results of the typical elements, it was shown that except for the grades of $\mathrm{K}_{2} \mathrm{O}, \mathrm{Na}_{2} \mathrm{O}$ and $\mathrm{K}_{2} \mathrm{O}+\mathrm{Na}_{2} \mathrm{O}$ in sample point 7 , the grades of the other points gradually decreased from the $1^{\text {st }}$ point to the $15^{\text {th }}$ point. The trend was opposite in the grade of $\mathrm{SiO}_{2}$ and the percentage content of $\mathrm{SiO}_{2}$ remained above $81 \%$ in all samples. The arithmetic mean grade of $\mathrm{K}_{2} \mathrm{O}$ and $\mathrm{Na}_{2} \mathrm{O}$ in the TG samples tested was $2.02 \%$ and $1.752 \%$ respectively. The total average grade of $\mathrm{K}_{2} \mathrm{O}+\mathrm{Na}_{2} \mathrm{O}$ was $3.77 \%$ and the average value of $\mathrm{SiO}_{2}$ content was $82.33 \%$.

$\mathrm{X}$-rays obtained from XRF analysis of the Tengger aeolian sand mixed sample (TS sample) were analyzed and the results were as tabulated in Table 5. It can be seen that the $\mathrm{Na}_{2} \mathrm{O}$ and $\mathrm{K}_{2} \mathrm{O}$ components in the TG sample are $2.449 \%$ and $1.920 \%$ respectively and the $\mathrm{Na}_{2} \mathrm{O}+\mathrm{K}_{2} \mathrm{O}$ combination is $4.369 \%$. The chemical composition of $\mathrm{SiO}_{2}$ and $\mathrm{Al}_{2} \mathrm{O}_{3}$ was $81.669 \%$ and $8.931 \%$ respectively which can

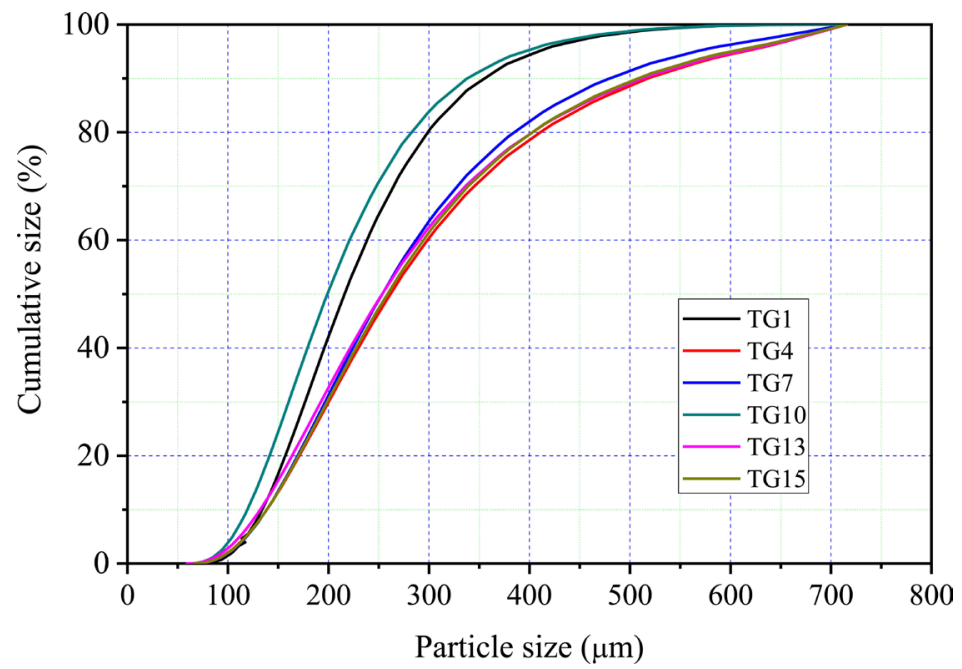

Figure 1. Laser diffraction size analysis presented as semi-log plot for the cumulative percentage size against logarithmic particle size.

Table 4. Sample chemical analysis results of typical elements in some TG samples (\%).

\begin{tabular}{cccccc}
\hline Sample code & Distance $(\mathrm{km})$ & $\mathrm{SiO}_{2}$ & $\mathrm{~K}_{2} \mathrm{O}$ & $\mathrm{Na}_{2} \mathrm{O}$ & $\mathrm{K}_{2} \mathrm{O}+\mathrm{Na}_{2} \mathrm{O}$ \\
\hline TG-1 & 30 & 81.10 & 2.468 & 1.913 & 4.381 \\
TG-4 & 34 & 83.52 & 2.583 & 1.627 & 4.210 \\
TG-7 & 38 & 81.90 & 2.645 & 1.915 & 4.561 \\
TG-10 & 41 & 81.39 & 1.605 & 1.909 & 3.513 \\
TG-13 & 45 & 82.07 & 1.570 & 1.616 & 3.186 \\
TG-15 & 53 & 83.99 & 1.234 & 1.534 & 2.768 \\
Average & 40.17 & $\mathbf{8 2 . 3 3}$ & $\mathbf{2 . 0 1 8}$ & $\mathbf{1 . 7 5 2}$ & 3.770 \\
\hline
\end{tabular}


be comprehensively recovered as quartz and feldspar respectively. Apart from the high percentage of $\mathrm{SiO}_{2}, \mathrm{Na}_{2} \mathrm{O}, \mathrm{K}_{2} \mathrm{O}$ and $\mathrm{Al}_{2} \mathrm{O}_{3}$, it was also detected that the sample is composed of $1.7 \% \mathrm{Fe}_{2} \mathrm{O}_{3}$ content which is an unwanted impurity in feldspar due to its colouring properties especially in the manufacture of high-class colourless glass that should contain a maximum of $0.1 \% \mathrm{Fe}_{2} \mathrm{O}_{3}$ although up to $0.3 \%$ is acceptable [13] [14].

The X-ray diffraction analysis (XRD) of the sample was as illustrated in XRD pattern as shown in Figure 2. The main minerals basically consistent in the

Table 5. TG mixed sample X-ray fluorescence spectrometry results (\%).

\begin{tabular}{cc}
\hline Chemical composition & Percentage (\%) \\
\hline $\mathrm{K}_{2} \mathrm{O}$ & 2.449 \\
$\mathrm{Na}_{2} \mathrm{O}$ & 1.920 \\
$\mathrm{SiO}_{2}$ & 81.669 \\
$\mathrm{Al}_{2} \mathrm{O}_{3}$ & 8.931 \\
$\mathrm{Fe}_{2} \mathrm{O}_{3}$ & 1.700 \\
$\mathrm{TiO}_{2}$ & 0.196 \\
$\mathrm{CaO}$ & 0.830 \\
$\mathrm{MgO}$ & 0.905 \\
$\mathrm{SO}_{3}$ & 0.017 \\
$\mathrm{P}_{2} \mathrm{O}_{5}$ & 0.048 \\
$\mathrm{Rb}_{2} \mathrm{O}$ & 0.008 \\
$\mathrm{SrO}_{\mathrm{ZrO}}$ & 0.022 \\
$\mathrm{BaO}_{2}$ & 0.014 \\
$\mathrm{LOI}$ & 0.069 \\
\hline
\end{tabular}

Note: The sample was tested after drying at $105^{\circ} \mathrm{C}$ for 2 hours.

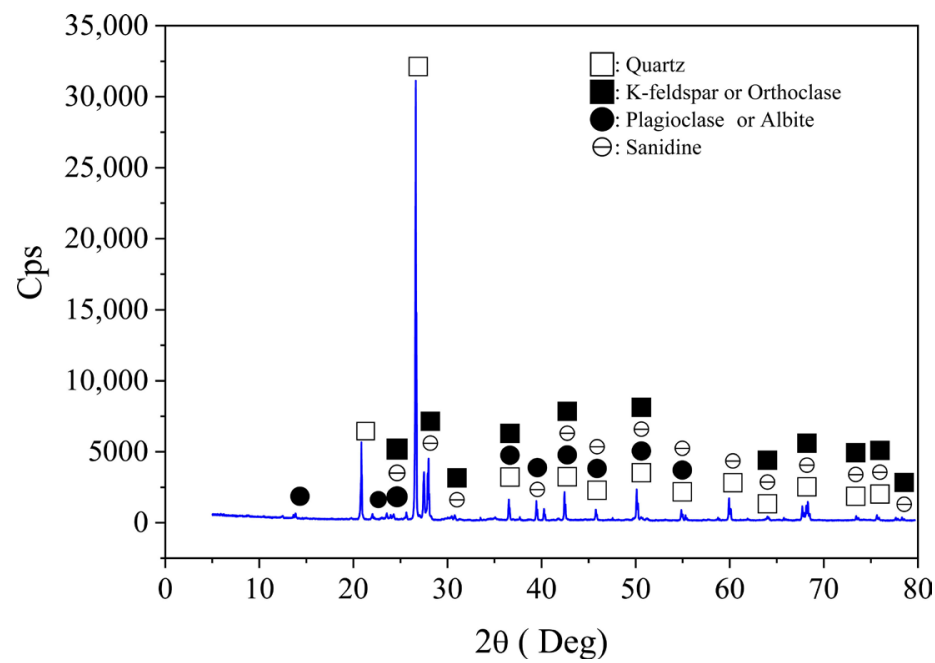

Figure 2. X-ray diffraction (XRD) analysis of mixed aeolian sand sample from Inner Mongolia. 
mineralogy of the TG samples were found to be quartz $\left(\mathrm{SiO}_{2}\right)$, potassium feldspar (K-feldspar) or orthoclase $\left(\mathrm{KAlSi}_{3} \mathrm{O}_{8}\right.$ ), oblique minerals such as plagioclase or albite $\left(\mathrm{NaAlSi}_{3} \mathrm{O}_{8}\right)$ and feldspar sanidine $\left(\mathrm{KAlSi}_{3} \mathrm{O}_{8}\right)$. Some impurity minerals had trace contents and could not be reflected in the XRD analysis.

Chemical analysis (Table 6) showed that the useful components of $\mathrm{Na}_{2} \mathrm{O}$ and $\mathrm{K}_{2} \mathrm{O}$ in the mixed sample were $2.385 \%$ and $1.982 \%$ respectively, and the total $\mathrm{K}_{2} \mathrm{O}+\mathrm{Na}_{2} \mathrm{O}$ was $4.367 \%$, the $\mathrm{SiO}_{2}$ was $82.43 \%$, and the $\mathrm{Al}_{2} \mathrm{O}_{3}$ was $7.68 \% . \mathrm{Fe}_{2} \mathrm{O}_{3}$ and $\mathrm{TFe}$ were $1.73 \%$ and $1.16 \%$, respectively; $\mathrm{CaO}$ and $\mathrm{MgO}$ were $1.97 \%$ and $2.20 \%$, respectively.

\subsection{Main Mineral Occurrences}

\subsubsection{Quartz}

Quartz, mainly occurring as $\mathrm{SiO}_{2}$, is the dominant mineral by estimation and is one of the minerals to be recovered from aeolian sands. By optical microscopy, it is about 46\%, irregular granular (shown in Figure 3, Figure 4), sub-circular, fine to medium sand structure, partly coarse sand structure, smooth surface, gray-white color (Figure 5, Figure 6) and has a particle size between $0.01-1.0 \mathrm{~mm}$. Also, about $6 \%$ quartz occurs as irregular, nearly elliptical, sub-circular, mainly siliceous sand grains composed of microcrystalline particles (as observed in Figure 6) and with a particle size between $0.05-0.8 \mathrm{~mm}$.

Table 6. Main multi-element chemical analysis results of Inner Mongolia aeolian sand TG mixed sample (\%).

\begin{tabular}{cccccccccc}
\hline Component & $\mathrm{K}_{2} \mathrm{O}$ & $\mathrm{Na}_{2} \mathrm{O}$ & $\mathrm{K}_{2} \mathrm{O}+\mathrm{Na}_{2} \mathrm{O}$ & $\mathrm{SiO}_{2}$ & $\mathrm{Al}_{2} \mathrm{O}_{3}$ & $\mathrm{Fe}_{2} \mathrm{O}_{3}$ & $\mathrm{TFe}$ & $\mathrm{CaO}$ & $\mathrm{MgO}$ \\
\hline Content/\% & $\mathbf{2 . 3 8 5}$ & $\mathbf{1 . 9 8 2}$ & 4.367 & $\mathbf{8 2 . 4 3}$ & 7.68 & 1.73 & 1.16 & 1.97 & 2.20 \\
\hline
\end{tabular}

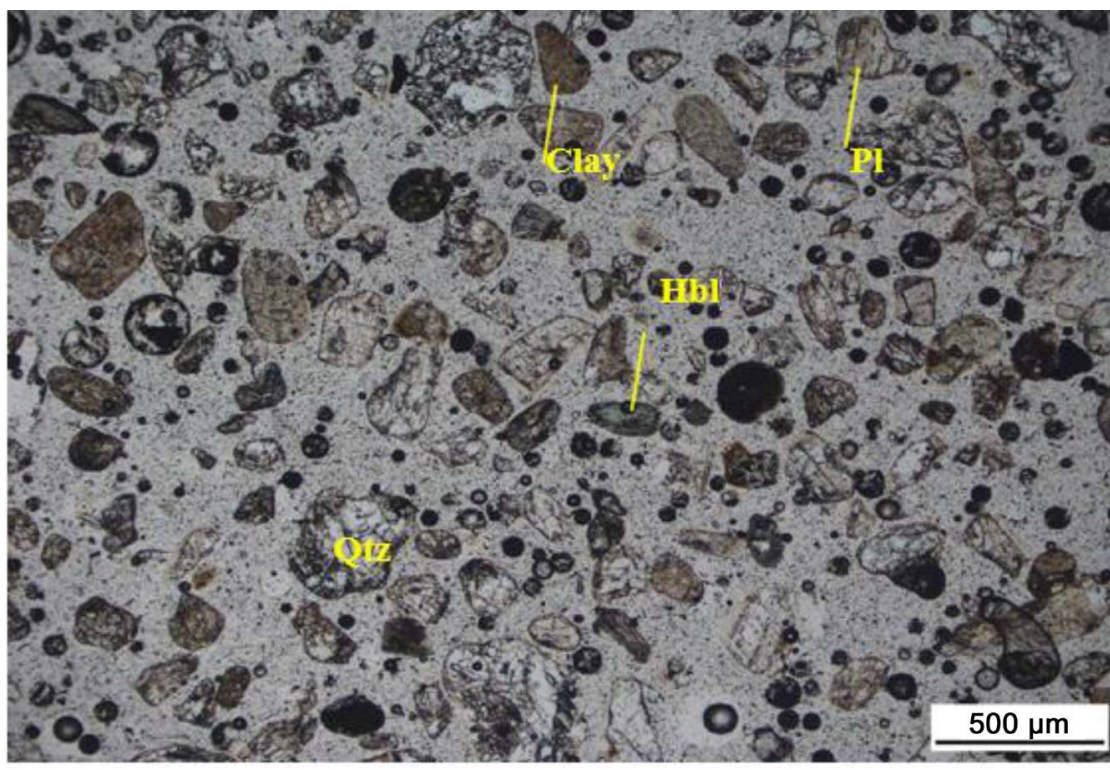

Figure 3. Irregular granular, sub-circular plagioclase $(\mathrm{Pl})$, medium-fine sand structure, granular quartz $(\mathrm{Qtz})$ and amphibole $(\mathrm{Hbl})$ under optical microscopic single polarized transmitted light $(-)$. 


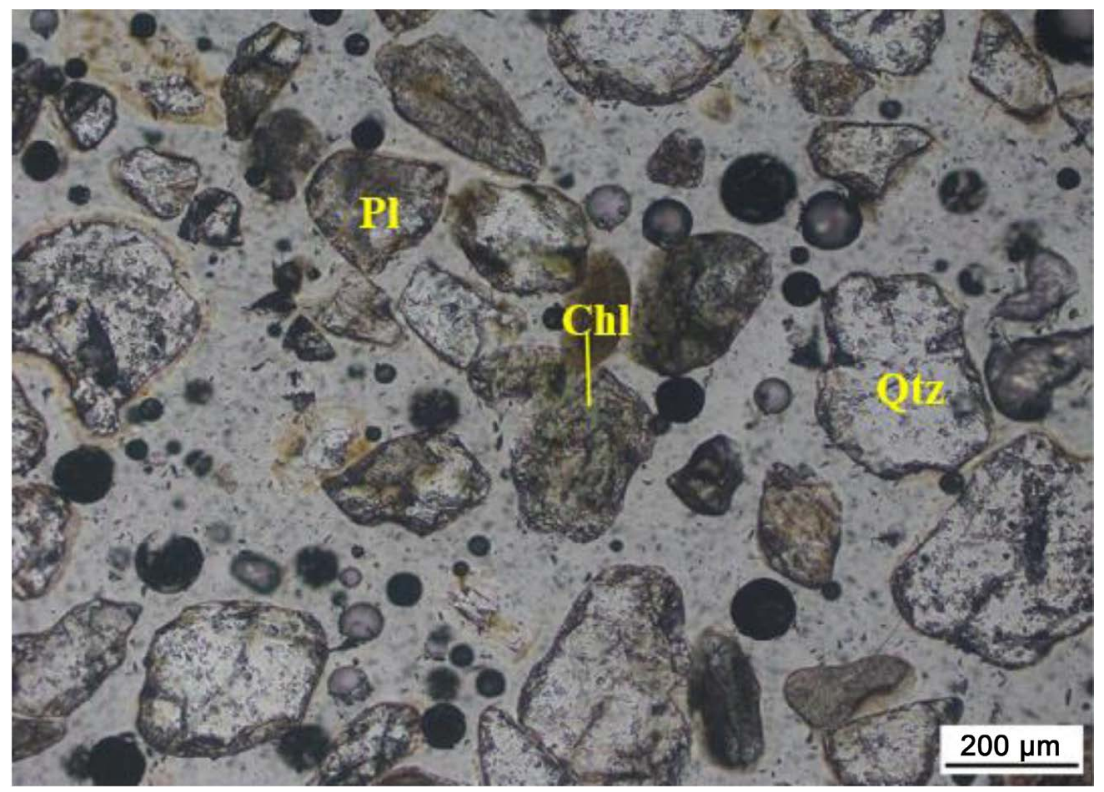

Figure 4. Quartz (Qtz) observed as irregularly granules, chlorite (Chl) and scaly metasomatic plagioclase $(\mathrm{Pl})$ under single polarized transmitted light $(-)$.

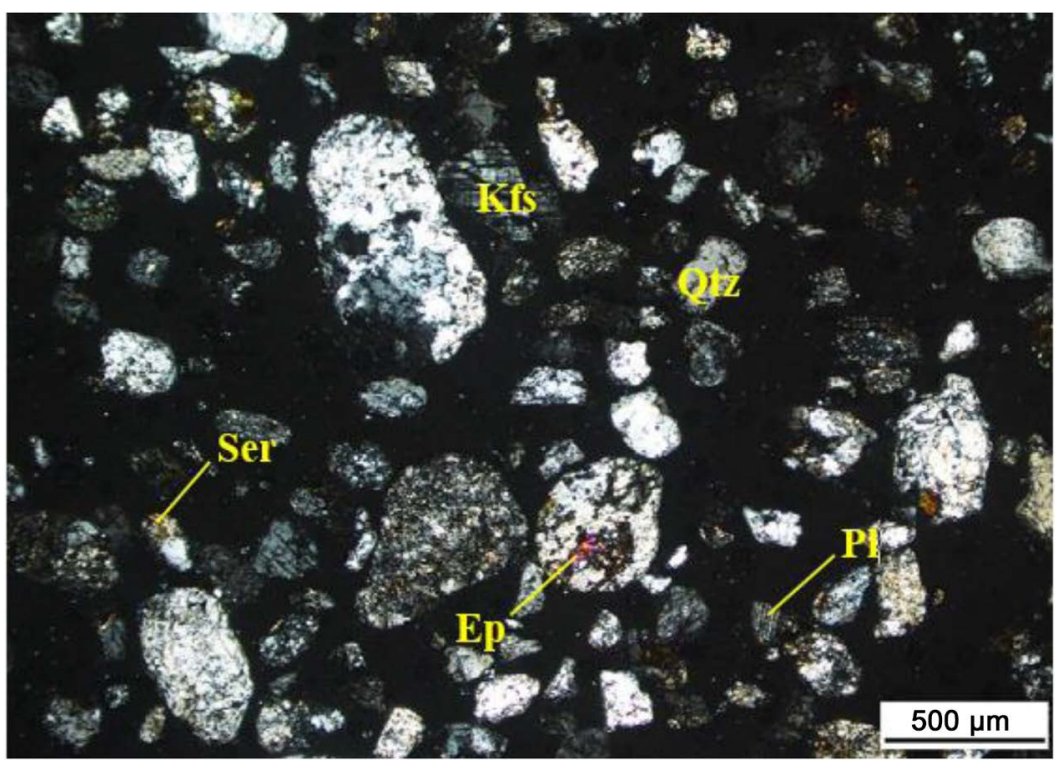

Figure 5. Plagioclase $(\mathrm{Pl})$ having a cleavage and polycrystalline twin structure, potassium feldspar (Kfs) observed as irregularly granular, sub-circular, with a visible double crystal lattice and striped structure, epidote (Ep), irregular granular metasomatic plagioclase $(\mathrm{Pl})$, quartz (Qtz) and sericite (Ser) under polarized orthogonal transmitted light $(+)$.

\subsubsection{Feldspar and Its Alterations}

Feldspar is also one of the minerals that can be recovered economically from aeolian sands. It mainly occurs in two forms which include potassium feldspar and plagioclase.

Potassium feldspar (Kfs) accounts for about $26 \%$ in the microscopic observations and it occurs as irregular granules which are sub-circular, having a medium to fine sand structure with a visible stripped lattice (as shown in Figure 5 


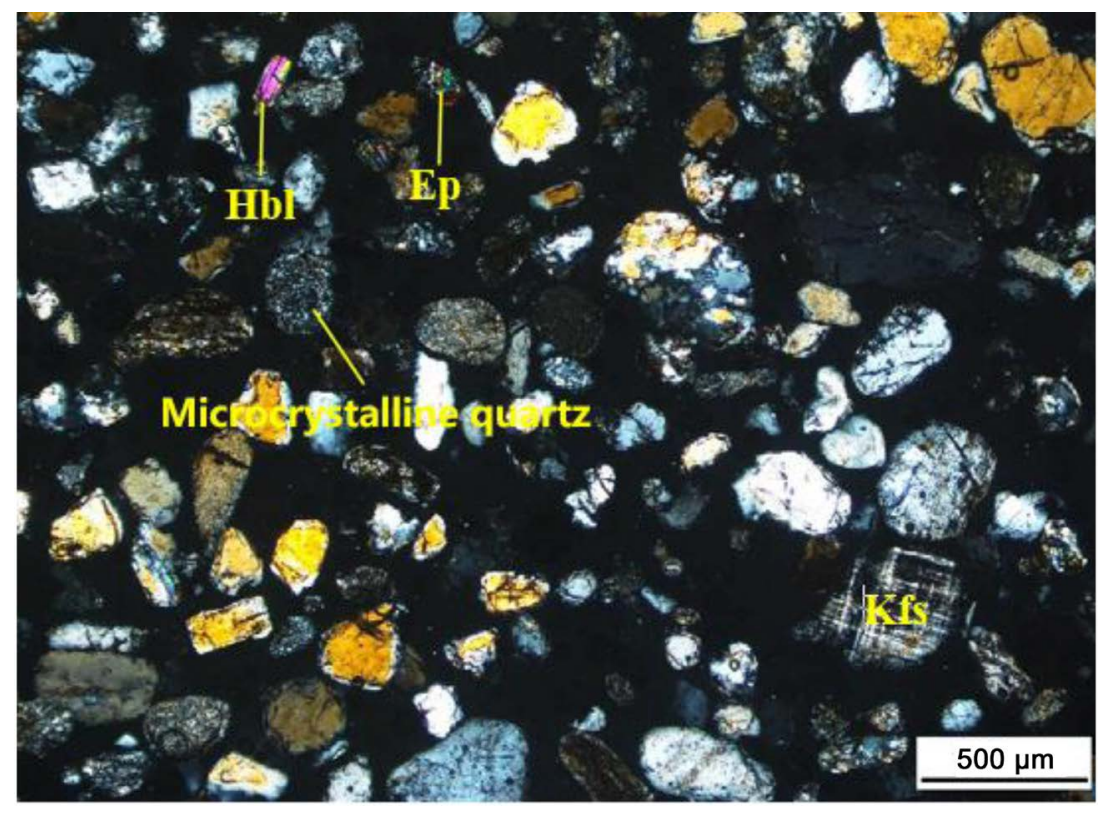

Figure 6. K-feldspar (Kfs) with twin lattice and striped structure, irregular granules of hornblende $(\mathrm{Hbl})$, visible cleavage; sand grains composed of microcrystalline quartz particles and epidote (Ep) under polarized orthogonal transmitted light $(+)$.

and Figure 6) with a particle size between $0.01-0.7 \mathrm{~mm}$. About $4 \%$ metasomatic potassium feldspar occurs as clayey particles (dust-like) (as observed in Figure 3) which are light brown yellow in colour under single polarized transmitted light.

Plagioclase $(\mathrm{Pl})$ is about $20 \%$ observed as irregular granules, sub-circular, medium-fine sand structure, partly coarse sand structure, visible cleavage and polycrystalline crystal structure (Figure 3, Figure 5), partially replaced by sericite, chlorite and epidote (Figure 4, Figure 5), with a blurred surface, and the particle size is between $0.01-0.8 \mathrm{~mm}$. Sericite (Ser) which is about $2 \%$, occurs as scaly metasomatic plagioclase (Figure 5), in a sporadic distribution, particle size between $0.01-0.1 \mathrm{~mm}$. Epidote (Ep) occurs in trace amounts as irregular grains (Figure 6) and metasomatic plagioclase (Figure 5) with a particle size between $0.01-0.2 \mathrm{~mm}$.

\subsubsection{Gangue Minerals}

Magnetite and ilmenite are the main gangue minerals present in the Tengger desert aeolian sand ore. Both are present in small amounts and have irregular granular shapes. Magnetite (Mt) has an approximate particle size of between $0.002-0.1 \mathrm{~mm}$ (Figure 7) while ilmenite (Ilm), which occurs to be distributed with hematite in a metamorphic structure (Figure 8), is observed as opaque with a particle size of between $0.002-0.1 \mathrm{~mm}$.

Limonite ( $\mathrm{Lm})$, amphibole ( $\mathrm{Hbl})$, chlorite (Chl) and tourmaline (Tur) as well as pyrite (Py) (Figure 9) are also all present in trace amounts. Limonite has a colloidal shape (Figure 10), brown-reddish colour and a particle size between $0.002-0.05 \mathrm{~mm}$. Amphibole has an irregular granular shape, brownish green colour (Figure 3 ) with a perfect cleavage (Figure 6) and a particle size of be- 
tween $0.01-0.1 \mathrm{~mm}$. On the other hand, chlorite occurs in a sheet-like form with a light green colour (Figure 4) and a size less than $0.1 \mathrm{~mm}$. Tourmaline also occurs occasionally with a light brownish yellow colour and a particle size of between 0.01 and $0.2 \mathrm{~mm}$.

\subsection{Association of Quartz, Feldspar and Gangue Minerals in Aeolian Sands}

\subsubsection{EMPA and Microzone Spectral Components of K-Feldspar}

Through observations and identification under the microscope, the main forms

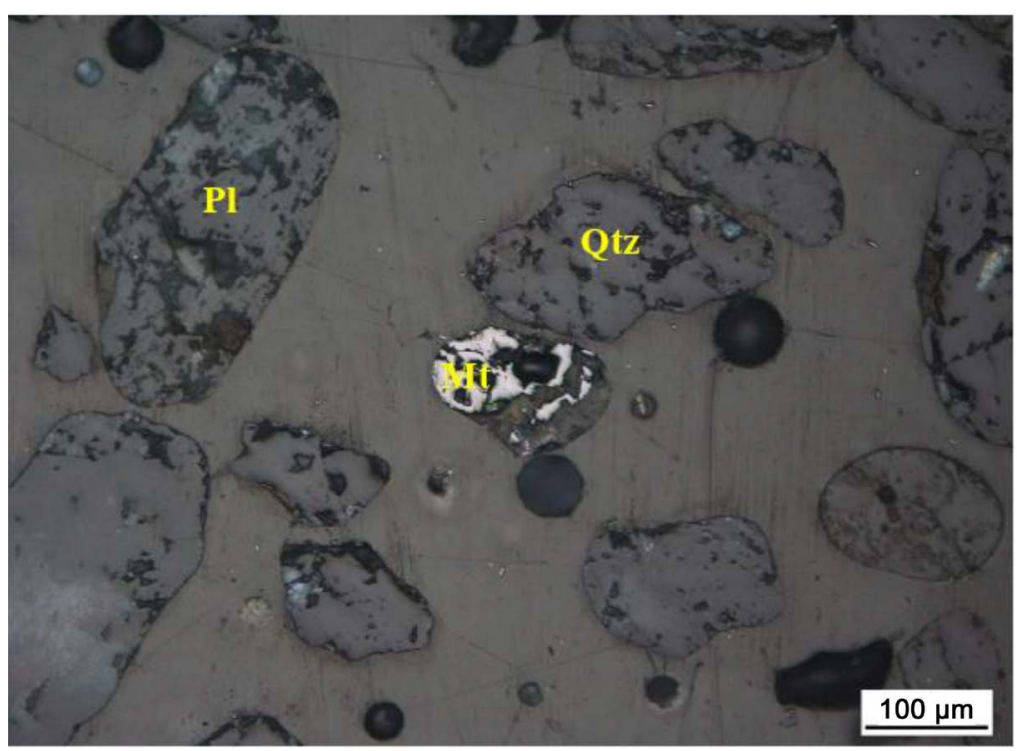

Figure 7. A small amount of magnetite (Mt) is irregularly granulated with quartz (Qtz) and plagioclase $(\mathrm{Pl})$ under reflective light.

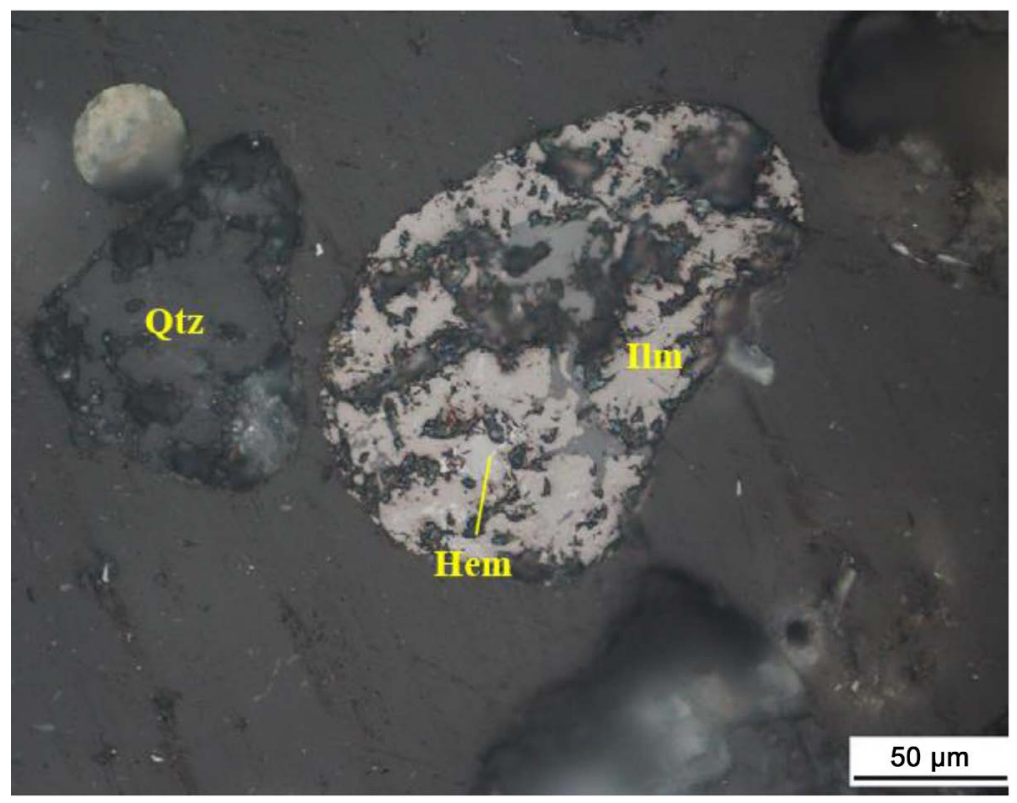

Figure 8. A small amount of ilmenite (Ilm) is irregularly granulated and partially replaced by hematite (Hem) in a sharp-angled structure and quartz (Qtz) under reflective light. 


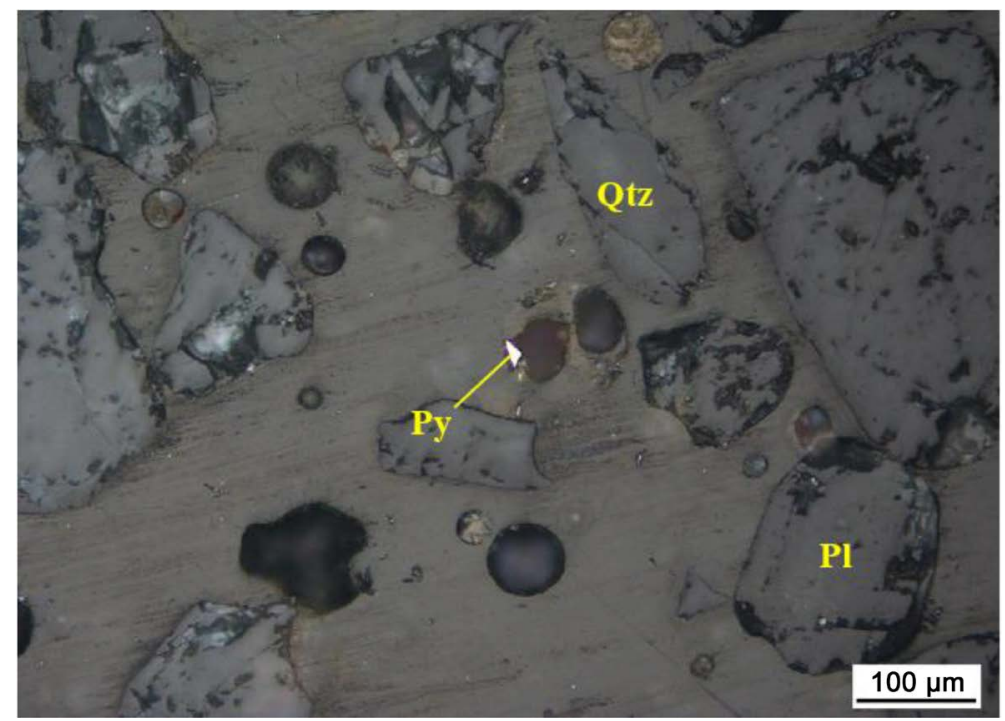

Figure 9. A small amount of pyrite (Py) is irregularly granulated with light quartz (Qtz) and plagioclase $(\mathrm{Pl})$ under reflective light.

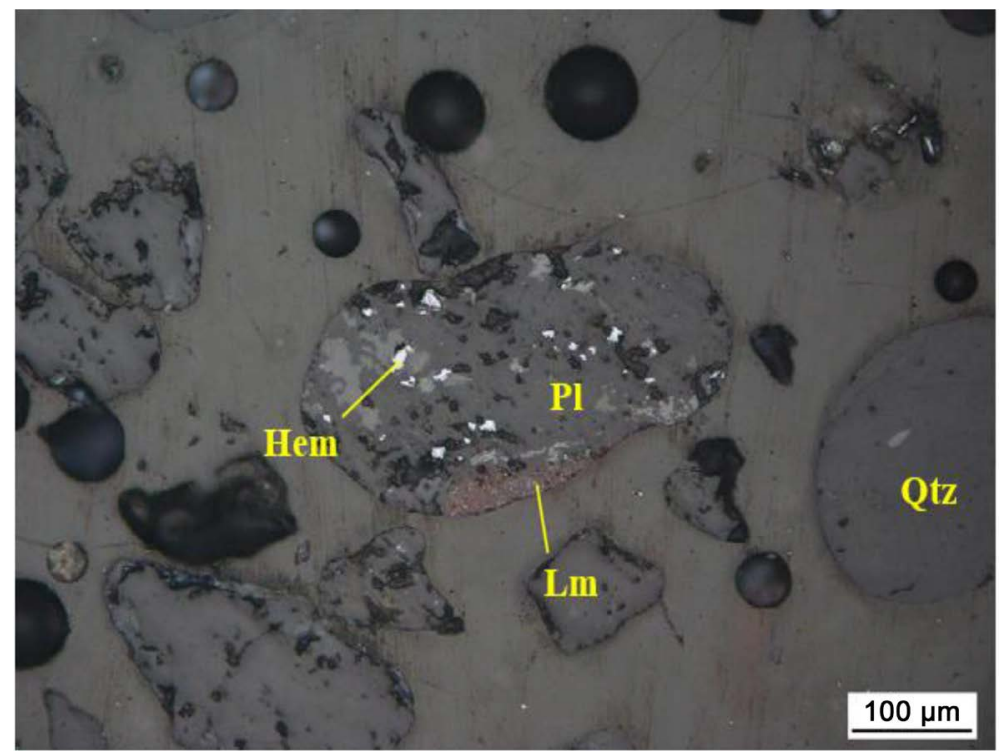

Figure 10. Hematite (Hem) observed as metamorphic ilmenite; irregular granular and colloidal limonite (Lm), quartz (Qtz) and plagioclase (Pl) under reflective light.

of $\mathrm{K}_{2} \mathrm{O}$ and $\mathrm{Na}_{2} \mathrm{O}$ were determined to be potassium feldspar (Kfs) and plagioclase $(\mathrm{Pl})$ minerals respectively. The concentration of potassium feldspar and sodium feldspar varied in different microzones (as noted in Figure 11, Figure 12, Figure 13 and Table 7). The chemical composition of K-feldspar (for the selected microzones) had an average potassium content of $9.02 \%$, a sodium content of $5.32 \%$, silicon content of $48.52 \%$, and aluminum content of $14.34 \%$. There were also some small amounts of titanium and calcium in some microzones. There was no iron content in the selected microzones data. However, characteristic peaks of iron were detected in the analysis of the energy spectrums. The highest potassium content was $18.23 \%$ and the lowest was $0.34 \%$. It 

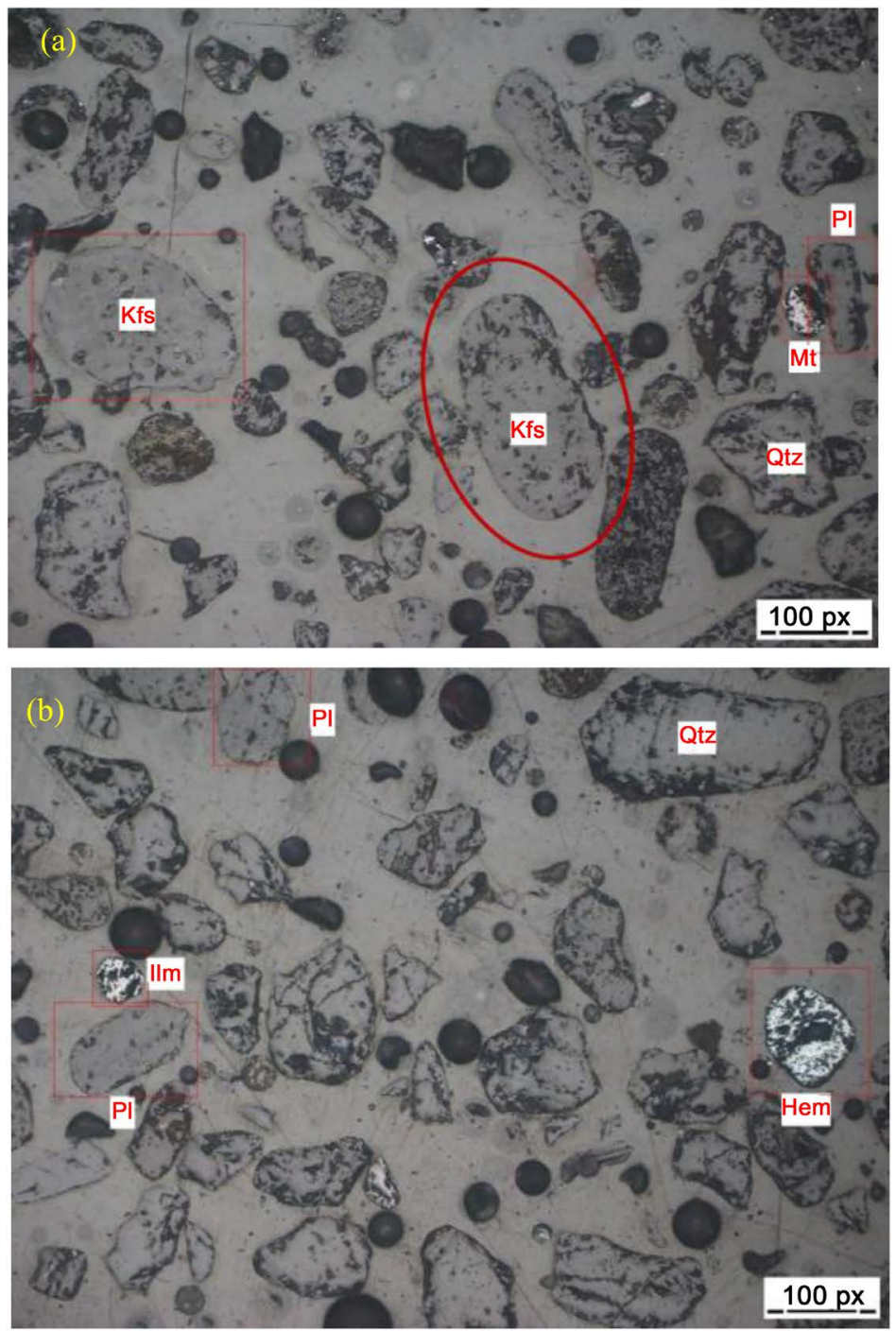

Figure 11. Micrograph showing the distribution of: (a) K-feldspar (Kfs), plagioclase (Pl), quartz (Qtz) and magnetite (Mt) and (b) plagioclase (Pl), quartz (Qtz), ilmenite (Ilm) and hematite (Hem) in Tengger aeolian sand.
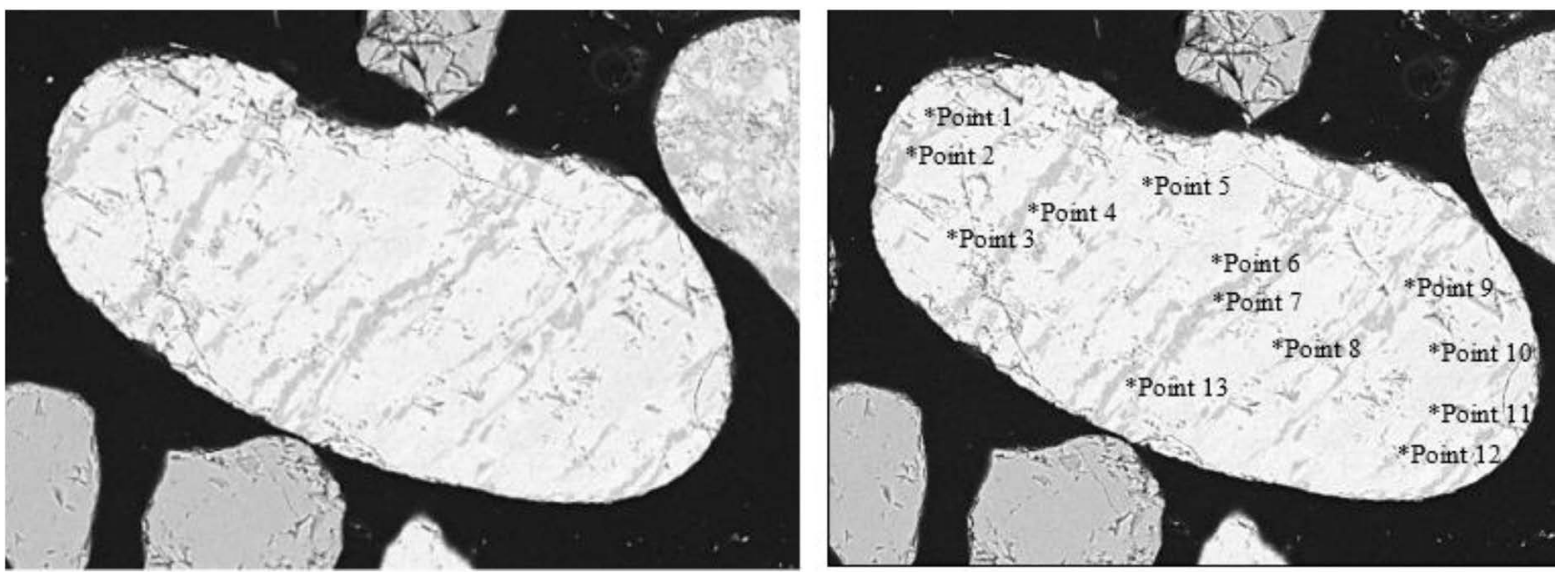

Figure 12. EMPA BEI (backscattered electron image) of potassium feldspar (Kfs) EMPA in the Tengger aeolian sand (The photo on the right is the microzone energy spectrum analysis point distribution). 


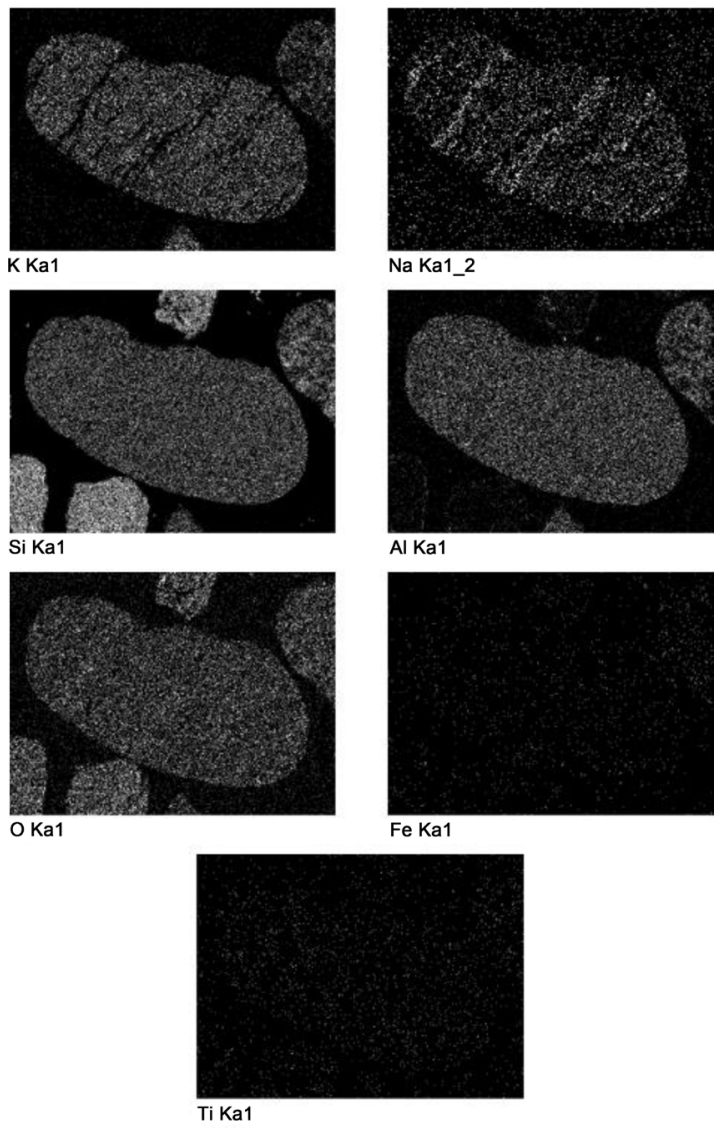

Figure 13. EMPA surface scan of potassium feldspar (Kfs) characteristic elements in Tengger desert aeolian sands: potassium $(\mathrm{K})$, sodium $(\mathrm{Na})$, silicon $(\mathrm{Si})$, aluminum (Al), oxygen $(\mathrm{O})$, iron $(\mathrm{Fe})$ and titanium $(\mathrm{Ti})$ surface scans.

Table 7. Results of energy spectrum micro-composition analysis of Tengger potassium feldspar (Kfs) (\%).

\begin{tabular}{cccccccccc}
\hline Spectrum & $\mathrm{K}$ & $\mathrm{Na}$ & $\mathrm{Si}$ & $\mathrm{Al}$ & $\mathrm{O}$ & $\mathrm{Ti}$ & $\mathrm{Fe}$ & $\mathrm{Ca}$ & Total \\
\hline 1 & 17.2 & 1.2 & 43.45 & 12.09 & 26.06 & 0 & 0 & 100.00 \\
2 & 0.34 & 9.85 & 47.49 & 13.96 & 28.36 & 0 & 0 & 100.00 \\
3 & 18.23 & 0.64 & 43.78 & 12.06 & 25.30 & 0 & 0 & 100.00 \\
4 & 1.37 & 8.95 & 48.15 & 13.77 & 27.77 & 0 & 0 & 100.00 \\
5 & 14.07 & 2.49 & 43.86 & 12.97 & 26.25 & 0.37 & 0 & 100.00 \\
6 & 16.02 & 1.82 & 43.37 & 12.43 & 26.36 & 0 & 0 & 100.00 \\
7 & 1.55 & 8.18 & 48.52 & 14.34 & 27.42 & 0 & 0 & 100.00 \\
8 & 16.96 & 1.46 & 43.39 & 12.35 & 25.84 & 0 & 0 & 100.00 \\
9 & 6.95 & 6.41 & 45.08 & 12.99 & 28.32 & 0 & 0 & 0.25 & 100.00 \\
10 & 16.09 & 1.76 & 44.07 & 12.14 & 25.94 & 0 & 0 & 100.00 \\
11 & 2.48 & 8.94 & 47.36 & 13.04 & 28.17 & 0 & 0 & 100.00 \\
12 & 2.41 & 8.90 & 46.84 & 13.33 & 28.53 & 0 & 0 & 100.00 \\
13 & 3.62 & 8.53 & 46.83 & 13.27 & 27.74 & 0 & 0 & 100.00 \\
Maximum & 18.23 & 9.85 & 48.52 & 14.34 & 28.53 & & & \\
Minimum & 0.34 & 0.64 & 43.37 & 12.06 & 25.30 & & & \\
Average & 9.02 & 5.32 & 45.55 & 12.98 & 27.08 & & & \\
\hline
\end{tabular}


also varied significantly for sodium with the highest being $9.85 \%$ and the lowest being only $0.64 \%$. The microzone X-ray energy spectrum composition of a typical K-feldspar mineral is shown in Figure 14.

\subsubsection{EMPA and Microzone Spectral Components of K-Feldspar}

It can be seen from Figure 11, Figure 15, Figure 16 and Table 8 that quartz and potassium-bearing feldspar minerals in the Tengger aeolian sands occur together. The quartz chemical composition (from the selected microzones) has an average $60.98 \%$ silicon, $5.10 \%$ aluminum and $2.12 \%$ potassium. Sodium was not detected in these microzones and part of the microzones contain traces of iron, titanium, calcium and magnesium with average values of $2.50 \%$ iron, $0.83 \%$ titanium, $0.38 \%$ calcium and $2.11 \%$ magnesium. This showed that the mineral association of quartz in the aeolian sands is complex and has quite a number of impurities to be separated in case it is being recovered for industrial use. It indicated that in order to obtain a higher quality quartz concentrate product, the ore should be finely ground to obtain a higher liberation degree. Typical quartz microzone X-ray energy spectrum composition diagrams are shown in Figure 17.
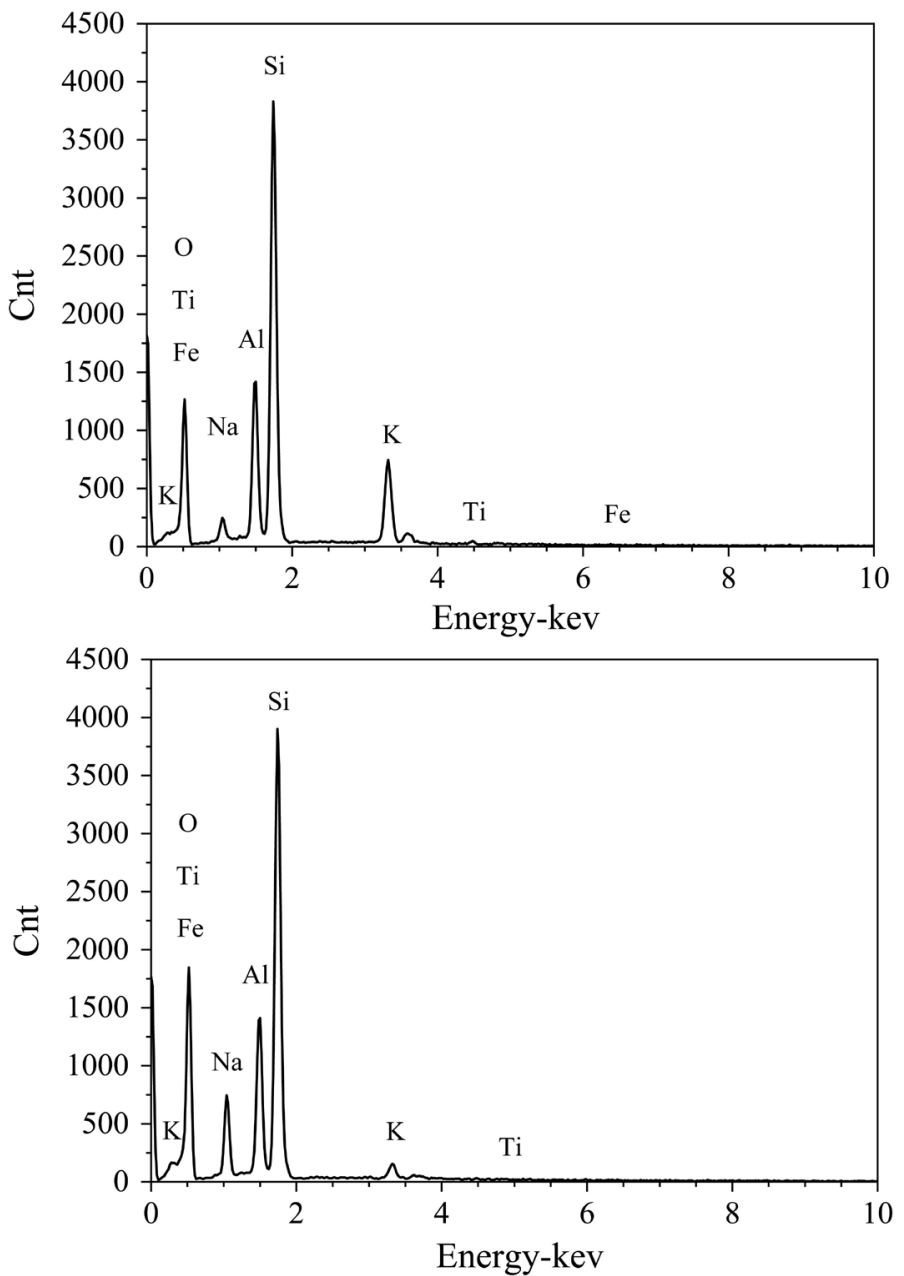

Figure 14. X-ray energy spectrum composition of K-feldspar microzone points (spectrum 5 and spectrum 12 respectively). 

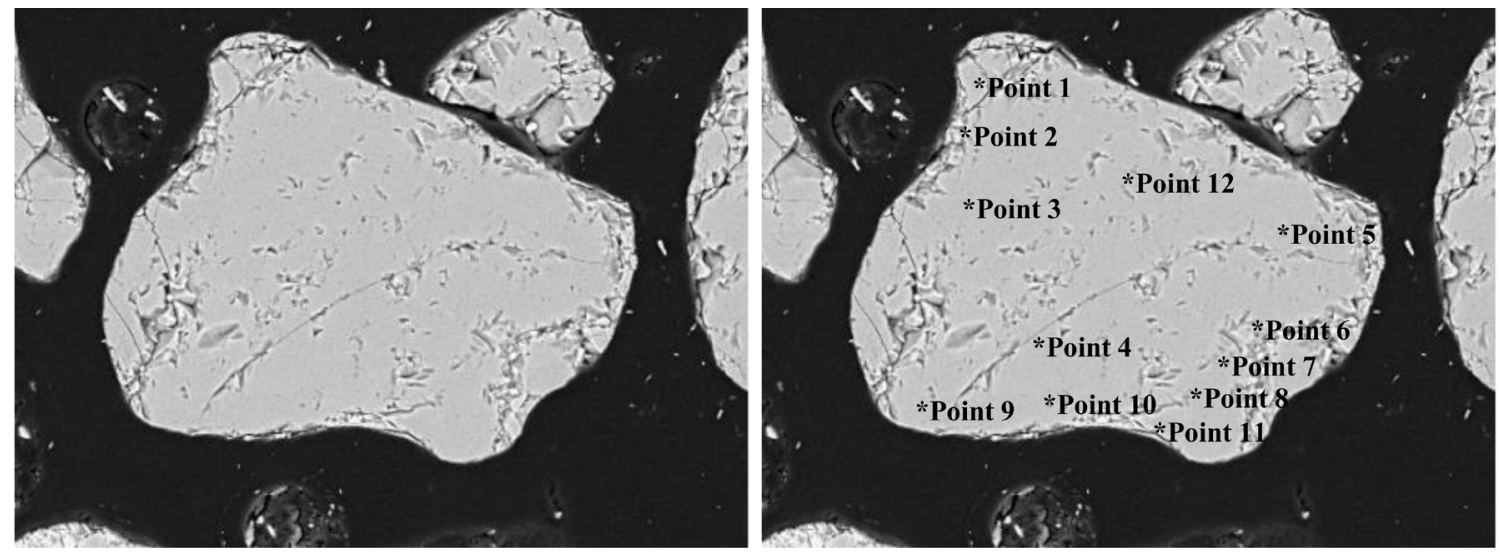

Figure 15. EMPA BEI of quartz (Qtz) EMPA in Tengger aeolian sand (The photo on the right is the microzone energy spectrum analysis point distribution).
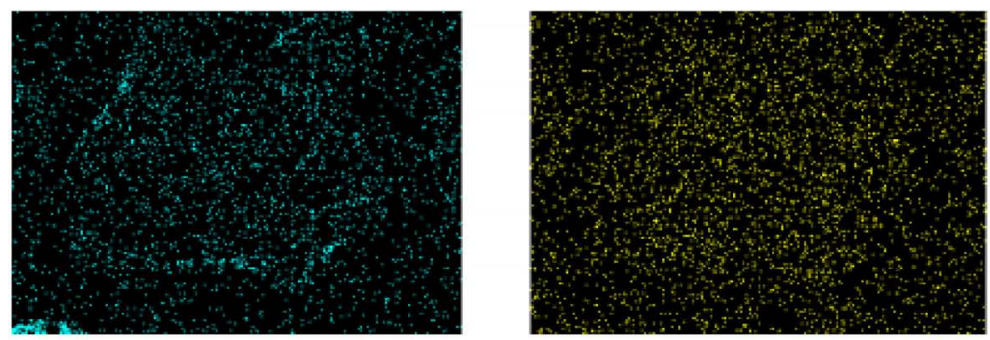

K Ka1

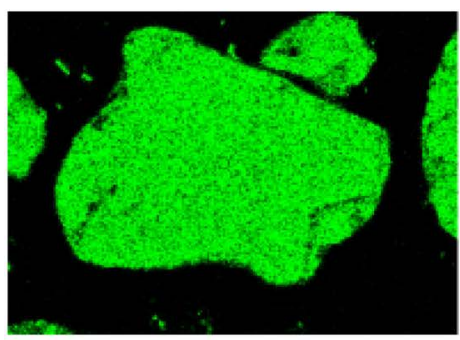

Si Ka1

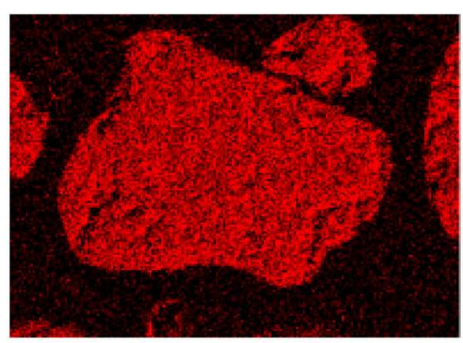

O Ka1
Na Ka1_2

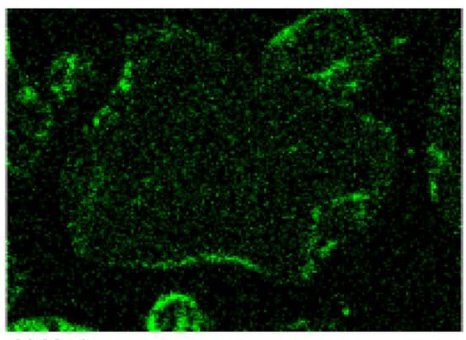

Al Ka1

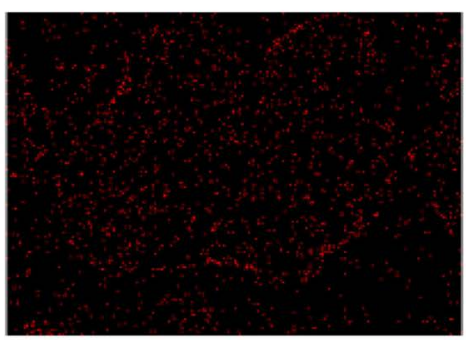

Fe Ka1

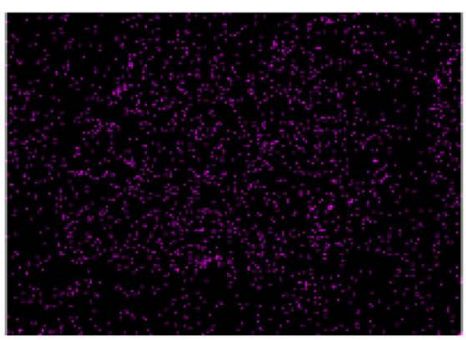

Ti Ka1

Figure 16. EMPA scan of quartz (Qtz) characteristic elements in Tengger aeolian sands: Surface scans of potas$\operatorname{sium}(\mathrm{K})$, sodium $(\mathrm{Na})$, silicon $(\mathrm{Si})$, aluminum $(\mathrm{Al})$, oxygen $(\mathrm{O})$, iron $(\mathrm{Fe})$ and titanium $(\mathrm{Ti})$. 
Table 8. Results of energy spectrum micro-composition analysis of Tengger quartz (Qtz) (\%).

\begin{tabular}{|c|c|c|c|c|c|c|c|c|c|c|}
\hline Spectrum & K & $\mathrm{Na}$ & $\mathrm{Si}$ & $\mathrm{Al}$ & $\mathrm{O}$ & $\mathrm{Fe}$ & $\mathrm{Ti}$ & $\mathrm{Ca}$ & $\mathrm{Mg}$ & Total \\
\hline 1 & 0 & 0 & 68.93 & 0 & 31.07 & 0 & 0 & & & 100.00 \\
\hline 2 & 6.62 & 0 & 33.71 & 19.48 & 27.31 & 5.76 & 4.71 & 0.23 & 2.18 & 100.00 \\
\hline 3 & 0 & 0 & 69.52 & 0 & 30.48 & 0 & 0 & & & 100.00 \\
\hline 4 & 0 & 0 & 68.98 & 0 & 31.02 & 0 & 0 & & & 100.00 \\
\hline 5 & 0 & 0 & 67.82 & 0 & 32.18 & 0 & 0 & & & 100.00 \\
\hline 6 & 8.78 & 0 & 54.17 & 14.65 & 12.95 & 6.02 & 2.34 & & 1.08 & 100.00 \\
\hline 7 & 0 & 0 & 68.37 & 0 & 31.63 & 0 & 0 & & & 100.00 \\
\hline 8 & 0.38 & 0 & 69.34 & 1.04 & 28.79 & 0 & 0.45 & & & 100.00 \\
\hline 9 & 5.10 & 0 & 46.38 & 13.34 & 21.79 & 8.85 & 1.44 & 0.42 & 2.67 & 100.00 \\
\hline 10 & 4.51 & 0 & 47.74 & 12.68 & 21.70 & 9.34 & 1.05 & 0.49 & 2.49 & 100.00 \\
\hline 11 & 0 & 0 & 68.20 & 0 & 31.80 & 0 & 0 & & & 100.00 \\
\hline 12 & 0 & 0 & 68.58 & 0 & 31.42 & 0 & 0 & & & 100.00 \\
\hline Maximum & 8.78 & 0 & 69.52 & 19.48 & 32.18 & 9.34 & 4.71 & 0.49 & 2.67 & \\
\hline Minimum & 0 & 0 & 33.71 & 0 & 12.95 & 0 & 0 & 0.23 & 1.08 & \\
\hline Average & 2.12 & 0.00 & 60.98 & 5.10 & 27.68 & 2.50 & 0.83 & 0.38 & 2.11 & \\
\hline
\end{tabular}
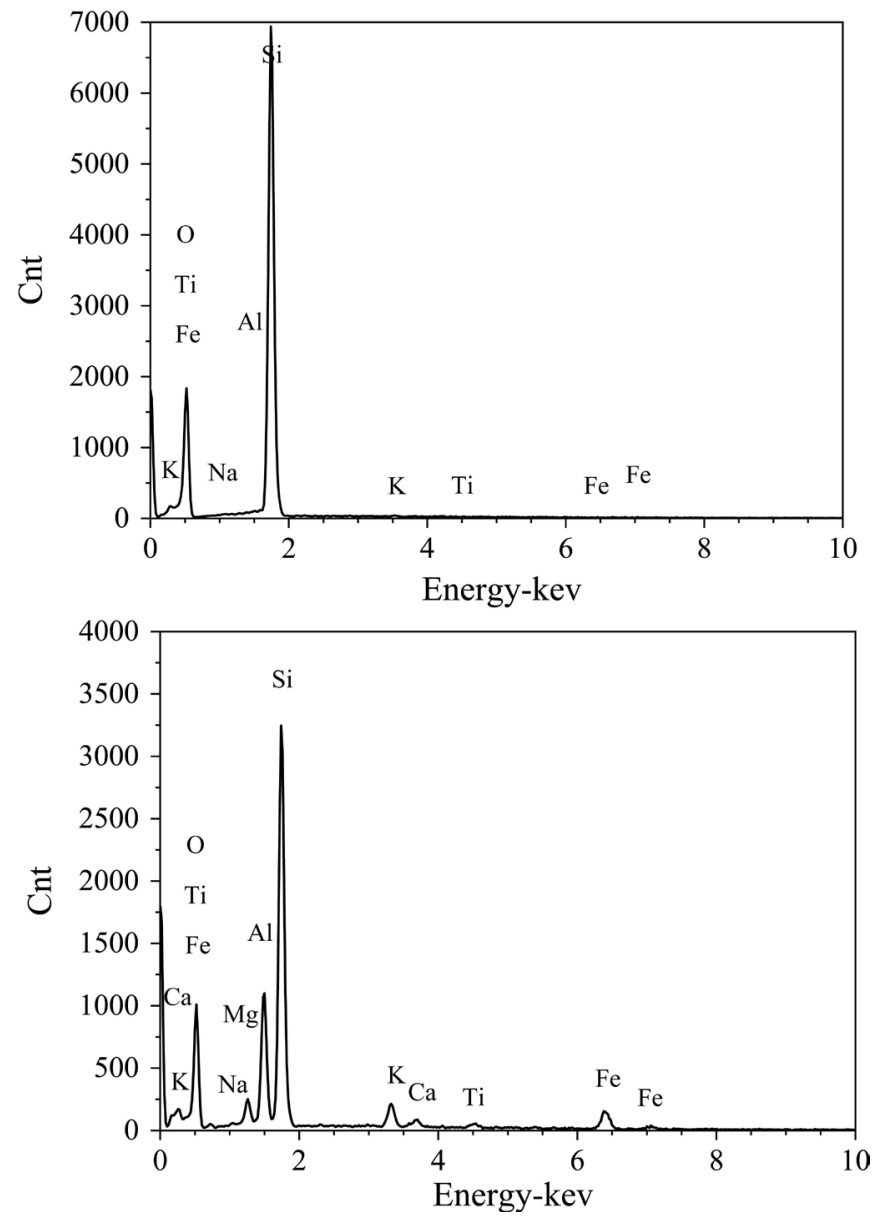

Figure 17. X-ray energy spectrum composition of typical quartz micro-zone points (spectrum 4 and 10 respectively). 


\subsubsection{EMPA and Microzone Spectral Components of K-Feldspar}

Microscopic observations showed that there were iron impurities in form of magnetite, hematite and ilmenite in the aeolian sands (Figure 11(a) and Figure 11(b)) which mostly occurred independently. EMPA and energy spectrum microzone analysis (Figure 18, Figure 19, Figure 20 and Table 9) indicated that magnetite particles are nearly independent in Tengger aeolian sands with high iron and oxygen element contents in the particles. The outer edge had a high aluminum content, a small amount of silicon, vanadium and other elements. Some microzones also contain elements such as potassium and magnesium with the outer edge of the particles having visible well-developed cleavages.

Since feldspar and quartz have been identified as the main economically valuable minerals, impurities including mica, titanium and iron minerals must be removed in order to suit ceramic and glass industry specification where they are mainly used. In relation to the above impurities and gangue minerals, the most suitable flowsheet for beneficiation could involve grinding, desliming and classification, then magnetic separation and flotation separations. The main methods of flotation for separating quartz and feldspar include the HF, non-fluoride and non-collector approaches. The HF method of quartz-feldspar separation where hydrofluoric acid is used as an activator for feldspar and primary amines used as collectors at a of pH 2-3 is the most well-known [5] [15]. Since HF is hazardous to the environment, HF-free reagents can be used, such as EDTA being used as a modifier in the separation of feldspar from quartz in acidic circuits, hence the non-fluoride method [16]. In the non-collector flotation method, diluted HF solution is used and frothers added where the quartz floats from the feldspar. However, in this case, the quartz recovery depends on the frother type and concentration as well as the conditioning time of the HF [17] [18].

Figure 21 shows a typical example of quartz product under a microscope containing over $99.9 \% \mathrm{SiO}_{2}$ after concentration and purification processes. Trace amounts of impurities such as rutile, pyrite, hematite and limonite are still present,
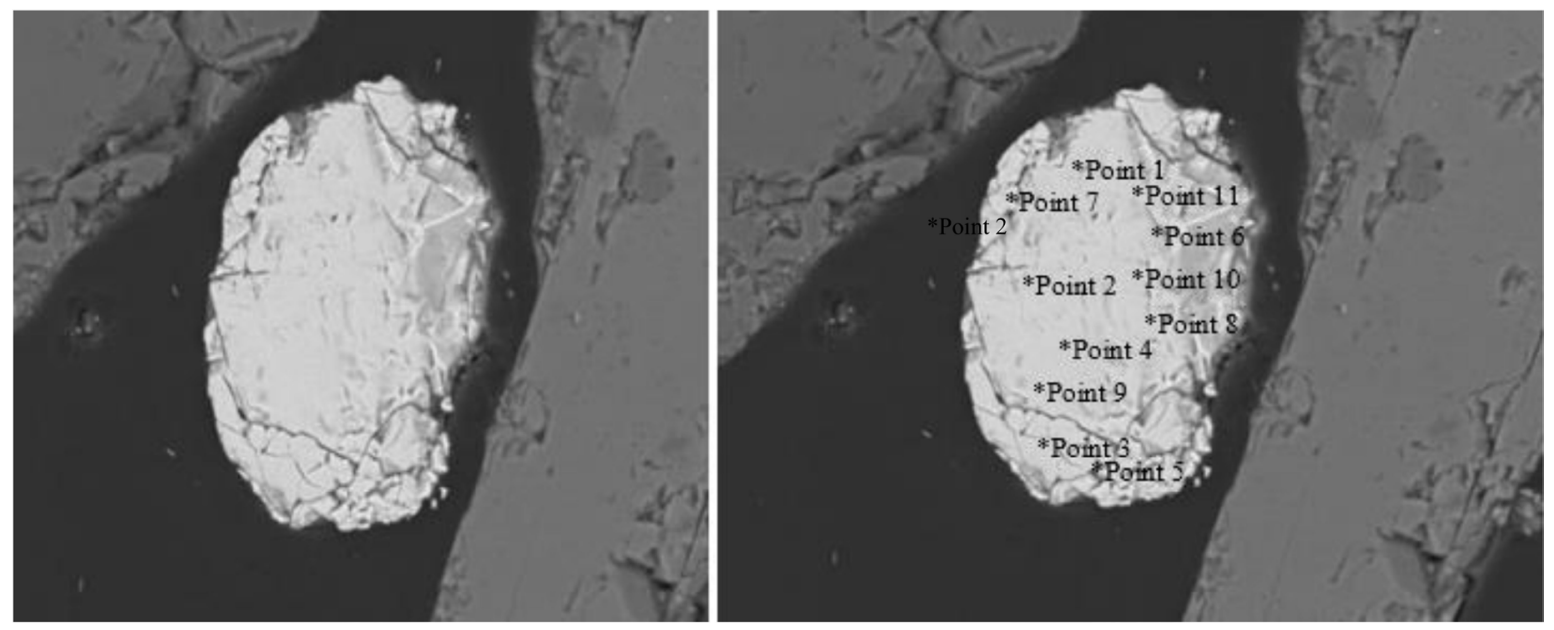

Figure 18. EMPA BEI (backscattered electron image) of magnetite (Mt) in Tengger aeolian sands (the photo on the right is the microzone energy spectrum analysis point distribution). 


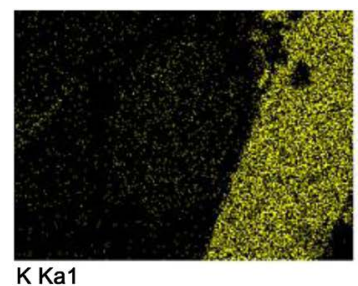

K Ka1

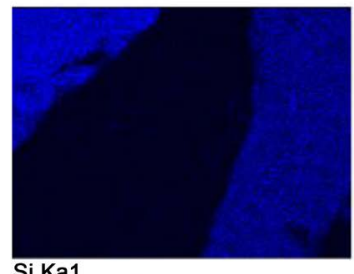

Si Ka1

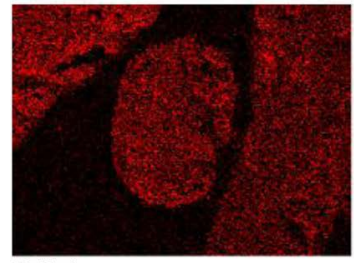

O Ka1

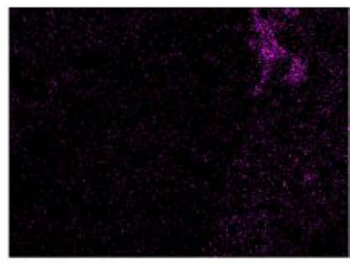

Na Ka1_2
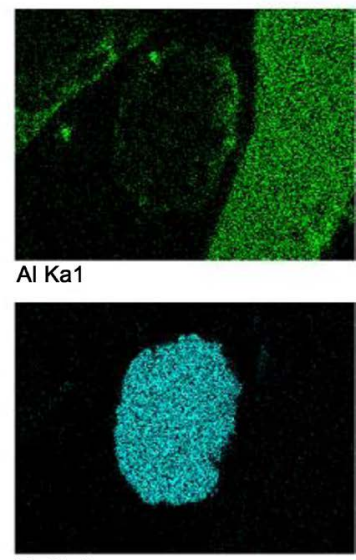

Fe Ka1

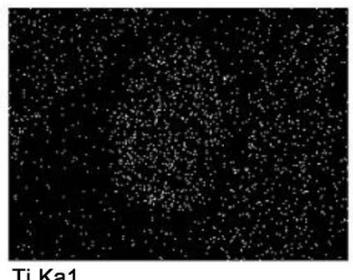

Figure 19. EMPA surface scan of magnetite (Mt) characteristic elements in Tengger aeolian sands; Surface scans of potassium $(\mathrm{K})$, sodium $(\mathrm{Na})$, silicon $(\mathrm{Si})$, aluminum $(\mathrm{Al})$, oxygen $(\mathrm{O})$, iron $(\mathrm{Fe})$ and titanium $(\mathrm{Ti})$.

Table 9. Analysis of energy spectrum microzone composition of Tengger magnetite (Mt) (\%).

\begin{tabular}{|c|c|c|c|c|c|c|c|c|c|}
\hline Spectrum & $\mathrm{K}$ & $\mathrm{Na}$ & $\mathrm{Si}$ & $\mathrm{Al}$ & $\mathrm{O}$ & $\mathrm{Fe}$ & $\mathrm{V}$ & $\mathrm{Mg}$ & Total \\
\hline 1 & 0 & 0 & 0 & 0 & 10.83 & 88.6 & 0.57 & & 100.00 \\
\hline 2 & 0 & 0 & 0.80 & 6.96 & 8.99 & 82.58 & 0.66 & & 100.00 \\
\hline 3 & 0 & 0 & 0 & 0 & 10.71 & 89.29 & & & 100.00 \\
\hline 4 & 0 & 0 & 0 & 4.79 & 10.89 & 83.27 & & 1.05 & 100.00 \\
\hline 5 & 0 & 0 & 0.61 & 2.18 & 8.20 & 88.28 & 0.73 & & 100.00 \\
\hline 6 & 0.26 & 0 & 0.65 & 4.79 & 14.21 & 79.52 & 0.56 & & 100.00 \\
\hline 7 & 0 & 0 & 0 & 0.55 & 10.84 & 88.03 & 0.57 & & 100.00 \\
\hline 8 & 0 & 0 & 0.64 & 6.12 & 6.75 & 86.48 & & & 100.00 \\
\hline 9 & 0 & 0 & 0 & 0 & 10.73 & 88.69 & 0.58 & & 100.00 \\
\hline 10 & 0 & 0 & 0.76 & 6.25 & 9.81 & 83.18 & & & 100.00 \\
\hline 11 & 0 & 0 & 0.90 & 12.50 & 6.64 & 77.00 & & & 100.00 \\
\hline Maximum & 0.26 & 0 & 0.90 & 12.50 & 14.21 & 89.29 & 0.73 & 1.05 & \\
\hline Minimum & 0 & 0 & 0 & 0 & 6.64 & 77.00 & 0.56 & 1.05 & \\
\hline Average & 0.02 & 0.00 & 0.40 & 4.01 & 9.87 & 84.99 & 0.61 & 1.05 & \\
\hline
\end{tabular}



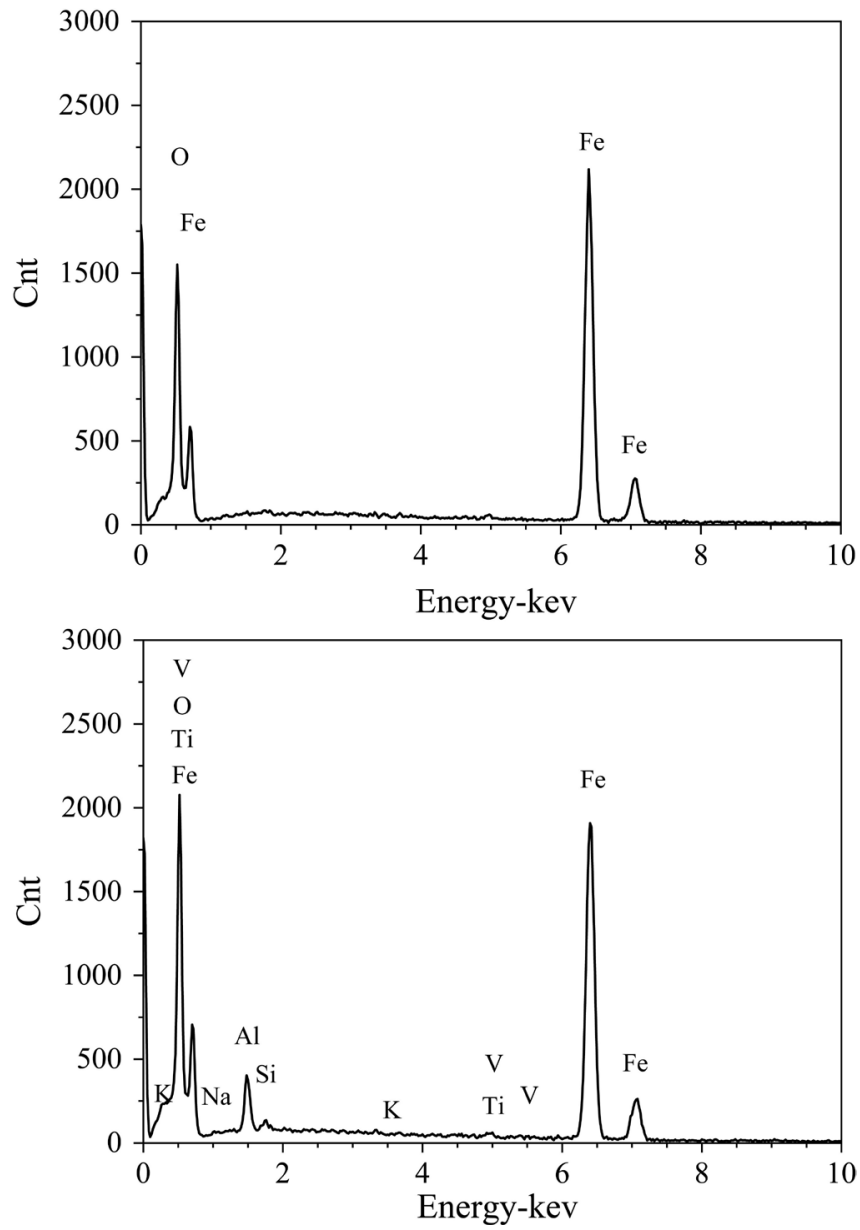

Figure 20. X-ray energy spectrum composition of typical magnetite microzone points (spectrum 3 and 6 respectively).
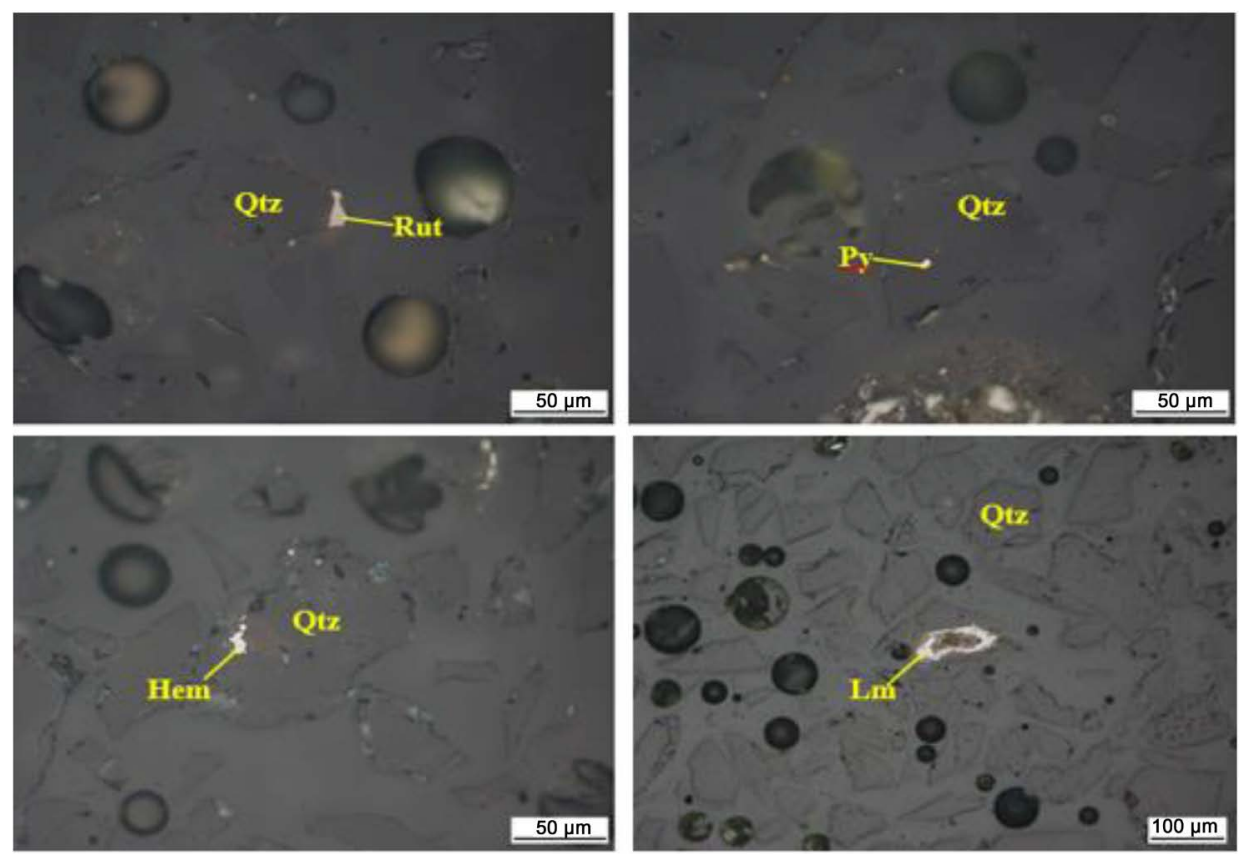

Figure 21. Microscopic observations of quartz product after concentration and purification. 
but their content is significantly low.

\section{Conclusions}

There are vast aeolian sand resources in China. The results obtained from this study show that Tengger desert aeolian sands can be a suitable source of quartz and feldspar for industrial applications. The useful recoverable feldspar mineral component in the sample contains $2.385 \% \mathrm{~K}_{2} \mathrm{O}$ and $1.982 \% \mathrm{Na}_{2} \mathrm{O}$ according to chemical analysis results. Quartz occurs as $\mathrm{SiO}_{2}$ which is about $82.43 \%$, being the most abundant mineral. All the other minerals accounted for about $10 \%$, but no other mineral could be recovered economically and hence they were treated as impurities. Chemical and mineralogical analyses confirmed the suitability of the deposit to be processed economically to separate the gangue minerals, which are mostly metallic and/or magnetic, to obtain high purity quartz and feldspar. The impurity minerals containing iron are mainly magnetite, hematite, pyrite, ilmenite and limonite.

From the microscopic observations, EMPA and micro-area spectral composition analysis, the mineral types in the sample are relatively simple and are mainly potassium feldspar, plagioclase and quartz with small amounts of sand, clay, sericite, ilmenite and other minerals. Potassium feldspar particle size ranges from 0.01 to $0.7 \mathrm{~mm}$, with plagioclase having a particle size of $0.01-0.8 \mathrm{~mm}$, and the quartz particle size is $0.01-0.7 \mathrm{~mm}$. Most of the impurity metal minerals are fine-grained. Since some of the gangue minerals are embedded on the target minerals, mostly feldspar, a proper and suitable grinding process will be necessary to liberate the minerals after which magnetic separation can be used to remove the magnetic impurities. Flotation can then be used to separate the feldspar and quartz minerals due to the difference in their zeta potential when treated under various flotation reagents. Therefore, future research could be determining how this ore can be beneficiated economically by use of magnetic separation and flotation methods, the suitable equipment, conditions and parameters involved.

\section{Acknowledgements}

The authors gratefully acknowledge financial support by the State Natural Science Foundation of China (No. 51874219) and the National Thirteenth-Five Years Key Research and Development Program of China (No. 2017YFC0703202).

\section{Conflicts of Interest}

The authors declare no conflicts of interest regarding the publication of this paper.

\section{References}

[1] Elipe, M.G. and Lopez-Querol, S. (2014) Aeolian Sands: Characterization, Options of Improvement and Possible Employment in Construction-The State-of-the-Art. 
Construction and Building Materials, 73, 728-739.

https://doi.org/10.1016/j.conbuildmat.2014.10.008

[2] Wintle, A.G. (1993) Luminescence Dating of Aeolian Sands: An Overview. Geological Society, London, Special Publications, 72, 49-58.

https://doi.org/10.1144/GSL.SP.1993.072.01.06

[3] El-Taher, A. (2010) Elemental Content of Feldspar from Eastern Desert, Egypt, Determined by INAA and XRF. Applied Radiation and Isotopes, 68, 1185-1188. https://doi.org/10.1016/j.apradiso.2010.02.002

[4] Zhang, Y., et al. (2018) Systematic Review of Feldspar Beneficiation and Its Comprehensive Application. Minerals Engineering, 128, 141-152.

https://doi.org/10.1016/j.mineng.2018.08.043

[5] Gaied, M. and Gallala, W. (2015) Beneficiation of Feldspar Ore for Application in the Ceramic Industry: Influence of Composition on the Physical Characteristics. Arabian Journal of Chemistry, 8, 186-190.

https://doi.org/10.1016/j.arabjc.2011.04.011

[6] Honda, M., Yabuki, S. and Shimizu, H. (2004) Geochemical and Isotopic Studies of Aeolian Sediments in China. Sedimentology, 51, 211-230.

https://doi.org/10.1111/j.1365-3091.2004.00618.x

[7] Rinaldi, R. and Llovet, X. (2015) Electron Probe Microanalysis: A Review of the Past, Present, and Future. Microscopy and Microanalysis, 21, 1053-1069.

https://doi.org/10.1017/S1431927615000409

[8] Lavrent'ev, Y.G., Karmanov, N. and Usova, L. (2015) Electron Probe Microanalysis of Minerals: Microanalyzer or Scanning Electron Microscope? Russian Geology and Geophysics, 56, 1154-1161. https://doi.org/10.1016/j.rgg.2015.07.006

[9] Alevizos, G. and Repouskou, E. (2011) Ore Microscopy and Microanalysis of the Nickeliferous Iron Ores from Komnina Vermion Area (NW Greece). Geomaterials, 1, 46. https://doi.org/10.4236/gm.2011.12008

[10] Wills, B.A. and Finch, J. (2015) Wills' Mineral Processing Technology: An Introduction to the Practical Aspects of Ore Treatment and Mineral Recovery. Butterworth-Heinemann, Cambridge.

[11] Sultana, M.S., Zaman, M.N., Rahman, M.A., Biswas, P.K. and Nandy, P.K. (2018) Mineralogical and Physical Characterization of Clay of Sitakunda Anticline: Used for Ceramic Industries. Journal of Minerals and Materials Characterization and Engineering, 6, 333. https://doi.org/10.4236/jmmce.2018.63023

[12] Huang, F.-F., et al. (2015) Differentiated Rare-Element Mineralization in an Ongonite-Topazite Composite Dike at the Xianghualing Tin District, Southern China: An Electron-Microprobe Study on the Evolution from Niobium-Tantalum-Oxides to Cassiterite. Ore Geology Reviews, 65, 761-778. https://doi.org/10.1016/j.oregeorev.2014.08.008

[13] Hacifazlioglu, H., Kursun, I. and Terzi, M. (2012) Beneficiation of Low-Grade Feldspar Ore Using Cyclojet Flotation Cell, Conventional Cell and Magnetic Separator. Physicochemical Problems of Mineral Processing, 48, 381-392.

[14] Aliyu, Z.S., Garkida, A.D., Ali, E.A. and Dauda, M. (2015) Characterization of Feldspar by Instrumental Analytical Techniques. In: Characterization of Minerals, Metals, and Materials, Springer, Berlin, 291-297.

[15] Yusupov, T., Kirillova, E. and Lebedev, M. (2013) Tribochemical Treatment of Feldspathic-Quartz Ore in Froth Separation. Journal of Mining Science, 49, 290-295. https://doi.org/10.1134/S1062739149020123 
[16] Shehu, N. and Spaziani, E. (1999) Separation of Feldspar from Quartz Using EDTA as Modifier. Minerals Engineering, 12, 1393-1397. https://doi.org/10.1016/S0892-6875(99)00125-9

[17] Larsen, E. and Kleiv, R. (2015) Towards a New Process for the Flotation of Quartz. Minerals Engineering, 83, 13-18. https://doi.org/10.1016/j.mineng.2015.08.004

[18] Larsen, E. and Kleiv, R.A. (2016) Flotation of Quartz from Quartz-Feldspar Mixtures by the HF Method. Minerals Engineering, 98, 49-51.

https://doi.org/10.1016/j.mineng.2016.07.021 